\title{
THE ON- AND OFF-STATE GENERATIONS IN CLASSICAL MICROQUASARS. 3-D NUMERICAL HYDRODYNAMICAL SIMULATIONS ON HIGH RESOLUTION GRID IN THE CASE OF INTERMEDIATE MASS TRANSFER RATE IN ACCRETION DISK OF MICROQUASAR CYG X-1
}

\author{
V.V. Nazarenko \\ Astronomical Observatory, Odessa National University, \\ Shevchenko Park, Odessa, 65014, Ukraine, nazaret@te.net.ua
}

\begin{abstract}
In the present work we have computed the accretion disk time evolution over 50 orbital periods on high resolution grid (the grid size is equal to $140 * 180 * 140$ ) for microquasar CYG X-1 for the case of intermediate mass transfer rate (the initial one-point density is equal to $8.184 \cdot 10^{12} \mathrm{~cm}^{-3}$, that corresponds to mass transfer rate order of $5 \cdot 10^{-9}$ solar mass per year). Our task in the present research is to generate ON-OFF-states (high/soft + low/hard states) in the accretion disk of the given microquasar. For this purpose we will simulate the precession motion of an accretion disk (the precession period is equal to 8 orbital ones in the present simulations). Thus, our key goal in the present work is to show that the precession motion in an accretion disk of microquasars results in ON-OFF state production. We have used
\end{abstract} the radiation cooling explicitly to obtain the real magnitudes of temperature in the calculations. The results show that in disk over the precession motion the mass accretion rate modulation occurs. This modulation is such that the states of low accretion rate replaced by the high accretion rate states, thus this replacement occur on the very short time scales, order of $15 \div 20$ minutes that in turn makes about of 0.0025 of orbital period. The relation of the magnitude of accretion rate between both states is by a factor of 100 . The centre disk temperature also shows the strong modulations in the magnitudes. These temperature modulations are that that centre disk high temperatures are corresponding to the low mass accretion rate and centre disk low temperatures are corresponding to the high mass accretion rate. We interpret this situation as ON-OFF-state (high/soft low/hard states) generation in our calculations. The ON-state time intervals are equal to OFF-state time intervals and these intervals are equal to 2 precession periods. The calculations also show that the time intervals of OFF-state are longer in space below orbital plane relatively these intervals upper orbital plane. This circumstance is explained by as follows: the one-point stream motion is strong nonuniform over the precession motion. The most part of this stream is moving upper orbital plane and a gas is more dense in this space. Thus, a gas in space in the disk centre below orbital plane have the relatively small density and radiation cooling is not effective in this case. The temperatures are strong increased in this case and the jets are launched more often in the disk centre below orbital plane in our present research. Finally we may conclude that we show above haw the precession mechanism of ON-OFF-state (high/soft - low/hard states) generation is working in our present research.

Keywords: Stars: binaries - stars: jets - methods: numerical - hydrodynamics.

АНОТАЦІЯ. В представленій роботі ми виконали чисельне обчислення еволюції акреційного диску протягом 50 орбітальних періодів з використанням числової сітки високого розділення (розмір сітки $140 * 180 * 140)$ для мікроквазара CYG X-1, випадок проміжної швидкості переносу речовини, що дорівнює $5 \cdot 10^{-9} M_{\odot} /$ рік (початкова концентрація речовини в першій точці Лагранжа становить $\left.8.184 \cdot 10^{12} \mathrm{~cm}^{-3}\right)$. Перед нами стояла задача згенерувати включені та виключені стани в акреційному диску даного мікроквазара. Для вирішення поставленої задачі нам потрібно було змоделювати прецесійний рух акреційного диску (в наших обчисленнях прецесійний період дорівнює восьми орбітальним періодам). Таким чином, ключовим завданням даної роботи було показати, що прецесійний рух акреційного диску приводить до генерації включених та виключених станів такого диску. Ми використовували радіаційне охолодження в явному виді, щоб одержати реальні значення температури в обчисленнях. Результати обчислень показали, що в диску 
Odessa Astronomical Publications, vol. 33 (2020)

під час прецесійного руху модулюються сильні зміни швидкості акреції. Ці модуляції такі, що стани низької швидкості акреції змінюються станами високої швидкості акреції, це відбувається протягом дуже короткого проміжку часу, близько $15 \div 20$ хвилин, що відповідає 0.0025 орбітального періоду. Співвідношення між швидкостями високої та низької акреції складає величину близько 100. Температура в центрі диску під час прецесійного руху також показує сильні модуляції за величиною. Ці модуляції такі, що висока температура в центрі диску відповідає низькій швидкості акреції та, навпаки, низька температура в центрі диску відповідає високій швидкості акреціі. Ми інтерпретували наявність вказаних станів в наших обчисленнях як моделювання включених та виключених станів в акреційному диску. Обчислення показали, що часові інтервали виключених станів приблизно рівні часовим інтервалам включених станів і вони всі разом приблизно рівні двом прецесійним періодам. Обчислення також показали, що часові інтервали виключених станів в області нижче орбітальної площини за величиною значно більші аналогічних станів в області вище орбітальної площини. Це пов'язано з тим, що газовий потік, що рухається 3 першої точки Лагранжа, під час прецесійного руху диску рухається здебільшого вище орбітальної площини завдяки чому газ в центрі диску в цій області набагато щільніше, ніж газ в центрі диску нижче орбітальної площини. 3 цієї причини газ в області нижче орбітальної площини має високу температуру значно частіше завдяки тому, що тут радіаційне охолодження не ефективне. Таж сама причина приводить до того, що в наших обчисленнях в області нижче орбітальної площини джети запускаються набагато частіше. Таким чином, в представлених обчисленнях ми показали як працює прецесійний механізм генерації включених та виключених станів на прикладі мікроквазара CYG X-1.

\section{Introduction}

In the present research we have continued to simulate the $\mathrm{ON}$ - and OFF-states generations on the base of microquasar Cyg X-1 by the methods of 3-D numerical hydrodynamics (Nazarenko \& Nazarenko, 2014, 2015, 2016, 2017; Nazarenko, 2018, 2019). The present work is devoted to ON- and OFF-states simulations in accretion disk on the base of classical microquasar Cyg X-1 in the case of high resolution grid. The goal of the present research is to compute the donor's wind, one-point-stream formation, its motion in Roche lobe of accretor, accretion disk formation and it's slaved precession on high resolution grid to see haw the low numerical viscosity will be affects on the results. We have used such the overflow degree, that one is corresponding to the mass transfer rate order of $5 \cdot 10^{-9}$ solar mass per year.

\section{The numerical algorithm}

The description of the numerical algorithm in use in details is given in our previous works (Nazarenko \& Nazarenko, 2014, 2015, 2016, 2017; Nazarenko, 2018, 2019). Shortly, this algorithm is as follows: to resolve the non-stationary Euler's hydrodynamical equations we have used the astrophysical variant of "large-particles" code by Belotserkovskii and Davydov (Belotserkovskii \& Davydov, 1982); to simulate onepoint-stream we use the donor's atmosphere model that in turn is constructed on the base Kurucz's grid (Kurucz, 1979) with the donor's parameters; we use the free-flow boundary conditions allowing to a gas to flow freely via the calculation area boundaries; to calculate mass flow real temperature we use the radiation cooling explicitly (Cox \& Daltabuit, 1971). In the present calculation we use the rectangular coordinate system centred on the donor's centre. We have adopted the donor's mass to be equal to 40 solar mass and the accretor's mass to be equal to 10 solar mass. The precession period in the present simulations is about of 8 orbital periods. Hereafter all the distances will be given in units of the orbital separations; the temperature will be given in units of $\mathrm{EV}$; the density will be given in units of $10^{11} \mathrm{~cm}^{-3}$; the times in the figures (see below) are given in units of the precession period. The initial one-point density is equal to 81,84 . In the present simulations the grid size is equal to $140 * 180 * 140$. The cell sizes in orbital plane are equal to 0.00755 and this size in the vertical direction is equal to 0.01 . The last means that in our present simulations the jets will be launched on highness of 10000 Schwarzschild radiuses.

\section{The results}

Before a starting precession we run our simulations over 2.6 precession periods to show a stationary state in disk over long time. The precession starting is on time equal to -0.25 . After a precession starting we run our simulation over $9 \div 10$ precession periods to have the results over long time. This time interval is containing two ON-states and two OFF-states. The mass accretion rate in a disk over OFF-states are equal to $2.5 \cdot 10^{-10}$ solar mass per year. The mass accretion rate in a disk over on states are equal to $5.5 \cdot 10^{-8}$ solar mass per year. We show mass accretion rate in a disk versus time on Fig. 1. This figure shows that to ON-states are corresponding high mass accretion rate and on contrary to OFF-states are 


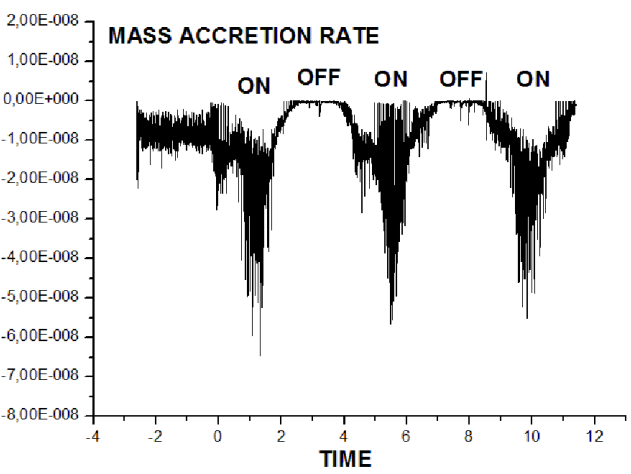

Figure 1: The mass accretion rate versus time.

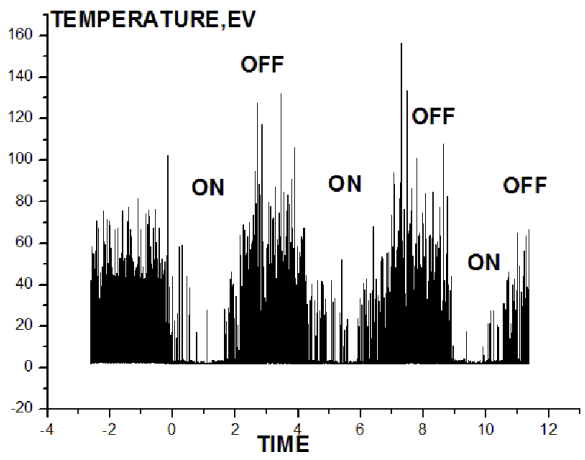

Figure 2: The central disk's temperature upper orbital plane versus time.

corresponding low mass accretion rate. This result is in the full corresponding with classical microquasars essential properties. The Fig. 2 and Fig. 3 show the central disk temperature upper and below orbital plane respectively. From these figures it is led that the transition between both states are occurring suddenly, on the very short time scale,order of 20 minutes of orbital time. The comparison of both the last two Figures show that the ON-state time intervals below orbital plane are much shortly relatively these intervals upper orbital plane. This circumstance is explained by the following: the distribution of one-point stream motion relatively the disk plane over the precession motion is strong nonuniform; the most part of this stream is moving upper orbital plane and this results in small density in the disk centre below orbital plane. As a result of it the OFF-state time intervals in the disk centre below orbital plane are very long. The last means that the jet launch below orbital plane must be occurring much often relatively this process upper orbital plane.

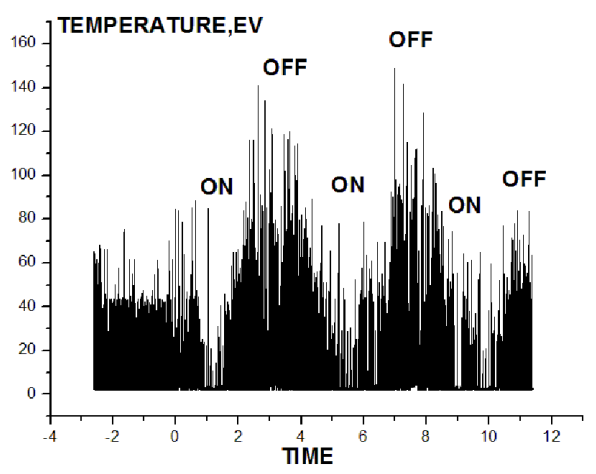

Figure 3: The central disk's temperature below orbital plane versus time.

\section{Summary and conclusions}

The present calculations show that in the case of intermediate mass transfer rate (order of $10^{9}-10^{8}$ solar mass per year) the time intervals of $\mathrm{ON}$ - and OFF-states are practically the same. The transition between both states is on very short time scale, order of 20 minutes of orbital plane. The low mass accretion rate is corresponding to OFF-states and high mass accretion rate is corresponding to ON-states. The relation between both mass accretion rates is order of 100 that is in good accordance with the observations commonly (Fender et al., 2003; Fender et al., 2004; Fabrika, 1993; Fabrika, 2004) and is in the very good accordance with observational data of Cyg X-1 (X-ray observations - Lachowicz et al., 2006) partially. The analyse of the present simulations show that the jet launch is occurring more often below orbital plane in comparison with this launch upper orbital plane.

\section{References}

Belotserkovskii O.M., Davydov Yu.M.: 1982, "The large particles code in gas dynamics", Moscow: Nauka, 391.

Cox D. P., Daltabuit E.: 1971, ApJ, 167, 113.

Fabrika S.N.: 1993, MNRAS, 261,241.

Fabrika S.: 2004, Astrophysics and Space Physics Reviews, 12, 1.

Fender R.P., Gallo E., Jonker P.: 2003, MNRAS, 343, L99.

Fender R.P., Belloni T., Gallo E.: 2004, MNRAS, 355, 1105.

Kurucz R.L.: 1979, ApJ. Suppl. Ser., 40, 1.

Lachowicz P. et al.: 2006, MNRAS, 368, 1025.

Nazarenko V.V., Nazarenko S.V.: 2014, Odessa Astron. Publ., 27, 137.

Nazarenko V.V., Nazarenko S.V.: 2015, Odessa Astron. Publ., 28, 171.

Nazarenko V.V., Nazarenko S.V.: 2016, Odessa Astron. Publ., 29, 82 .

Nazarenko V.V., Nazarenko S.V.: 2017, Odessa Astron. Publ., 30, 113.

Nazarenko V.V.: 2018, Odessa Astron. Publ., 31, 90. Nazarenko V.V.: 2019, Odessa Astron. Publ., 32, 70. 